Newfoundland and Labrador Studies

\title{
Terry Doyle. Dig
}

\section{Melanie Hurley}

Volume 35, Number 1-2, 2020

URI: https://id.erudit.org/iderudit/1076775ar

DOI: https://doi.org/10.7202/1076775ar

See table of contents

Publisher(s)

Faculty of Arts, Memorial University

ISSN

1719-1726 (print)

1715-1430 (digital)

Explore this journal

Cite this review

Hurley, M. (2020). Review of [Terry Doyle. Dig]. Newfoundland and Labrador

Studies, 35(1-2), 154-158. https://doi.org/10.7202/1076775ar

This document is protected by copyright law. Use of the services of Erudit (including reproduction) is subject to its terms and conditions, which can be viewed online.

https://apropos.erudit.org/en/users/policy-on-use/
This article is disseminated and preserved by Érudit.

Érudit is a non-profit inter-university consortium of the Université de Montréal, Université Laval, and the Université du Québec à Montréal. Its mission is to promote and disseminate research.

https://www.erudit.org/en/ 
Terry Doyle. Dig. St. John's: Breakwater Books, 2019. ISBN 978-1550-81759-1

When I think of Terry Doyle's Dig, the first word that comes to my mind is "abject" because of its trash motif, the structure of the stories, and its characters. In her famous Powers of Horror, Julia Kristeva defines the abject as that which disgusts us and which we consequently expel from our physical and social bodies, but which is nonetheless a part of us. The physical abject includes vomit and feces, while the social abject consists of individuals whose lives dominant society considers invalid. These people populate the margins of society, often going unseen and their stories going unheard. Dig opens a window on the lives of the poor, the drug-addicted, the desperate, and the lonely, showcasing experiences that the mainstream often lets go unexamined, and reminding us that such individuals are a part of our social world and cannot and should not be erased.

The collection's epigraph, a quotation from John Berger on the nature of trash, introduces the theme of abjection, using the timely topic of human waste materials to remind us that abject lives are a social construction rather than a natural fact. It reads:

People mix up everything. They throw everything away in the same place. That's how they make trash. There's no such thing as trash. Trash is the confusion we make throwing things out.

Trash is a social and environmental problem at this time, making this quotation an attention-grabbing choice. As part of an effort to combat the plastic waste that is destroying the oceans, Newfoundland is set to become the second province to ban plastic bags (Prince Edward Island was the first). Radio station VOCM regularly runs public service announcements that ask people not to litter. Canada recently (and rightfully) became the target of criticism when it dumped garbage in the Philippines. Trash, a human-made substance, is a problem that we 
must confront even if we would rather not see it. Likewise, we must confront the personal and social problems of our creation, issues that we also frequently avoid. They, too, remain within our borders and sometimes intrude upon our lives, forcing us to reckon with them.

Dig is not unique in Newfoundland literature in its use of trash to examine experiences of the abject, as Heather Smith's The Agony of Bun O'Keefe (2017) also does so, but Dig's open-ended stories are much more bleak than Smith's optimistic young adult novel, for, as the epigraph suggests, it focuses on the creation of abject individuals and the confusion that contact with the abject causes rather than on the escape from abject status, the topic of Smith's work. In Bun O'Keefe, the eponymous character's hoarder mother fills their house with other people's discards, and she has become a part of the trash, "nestl[ing] into a pile of garbage bags, a cup of tea balanced on her chest" (1-2). This woman and her house suffocate Bun, who has almost no contact with the outside world. However, after leaving her mother's dump, Bun finds a new home with a group of social misfits, choosing a family of her own making, and the novel ends happily with Bun taking her friend Busker Boy's hand (216).

Doyle's stories do not have such tidy, pretty conclusions. The first story, "Kid's Special," ends with its child protagonist receiving a note that reads "Fuck you, Kingsley" after a failed (because misguided) act of kindness (33): rather than gaining the friendship he sought, Kingsley falls further down the junior-high social scale. Other examples include "DIG," which concludes with its lead character, Brooks, tasting his date's cooking and thinking "I'd never tasted anything like it. And worry I never will again"(86), and "Hammerhead," which ends with the unnamed protagonist's girlfriend refusing him sex and their dog whining to get out (169-70). So, while Smith's Bun successfully escapes her unlivable life, Doyle's characters seem to be slipping deeper into the abject, floundering around in its confusion with no escape in sight.

Dig's abject characters are sometimes lead characters who grapple with their marginality, and sometimes secondary characters whom others try to suppress, but they are always fighting against the abject 
and erupting into our world through the narratives, forcing the audience to notice them, think about them, and grapple with the abject themselves. An example of the first type of abject character is Riley in "Graceland." Since Riley's father suffered a workplace injury, Riley has taken on a great deal of responsibility at home, and she also contests the "callousness" (44) she sees in the world, campaigning against everything from cruelty to animals (39-40) to the book tax (46). Unfortunately, the harder she works, the more exhausted and isolated she finds herself. Meanwhile, "Squat" contains a representative of the second type of abject character. In this story, protagonist Matt starts a job cleaning an abandoned building on Duckworth Street, and, when he finds evidence (in the form of dirty blankets, socks, debris from a fire, and the scent of urine) that a homeless person lives there, he tries to erase the person's existence. He throws the blankets and socks into one of his garbage bags, sweeps up the ashes with pieces of a cardboard box, and pours water on the stain left by the fire (94-95). Still not satisfied, he later arms himself with his great-grandfather's hunting knife, protecting himself against this invasion of the abject (99). Despite their differences, however, Riley and Matt both struggle against becoming abject themselves. Riley takes a job as an "assistant" to lawyer and social crusader Cheryl in order to prevent herself and her father from becoming homeless or complete charity cases. Ironically, though, she is another of Cheryl's causes (47, 50-52), and her job turns out to be doing the lawyer's housework (53), decreasing Cheryl's contact with dirt and increasing her own. Matt's job puts him in close contact with rubbish, and his stand against the homeless person is also a stand against the contaminating abject, against becoming a part of the trash. The stories show how easy it is to slide from socially accepted to social pariah, and they examine not only the abject, but our fear of becoming the abject.

Given the precarity of their lives, one may assume that Dig's characters are highly sympathetic, but most of them are actually remarkably off-putting; however, a distaste for them is consistent with the collection's subject matter, with our general revulsion on contact with abject substances. For example, "Can't Drink" opens with narrator Dan 
swearing at his girlfriend Chloe (115), immediately depicting him as a questionable partner. He proceeds to prove that he is a deadbeat, for he thinks about pot more than anything else, neglecting his girlfriend in its favour (122-23) and even losing his job for having THC in his system (127). Similarly, Charles, the protagonist of "Cul-de-Sac," is an ungrateful jerk. When Nevin, a high school acquaintance, offers to get him a much-needed job as a labourer on a construction site, he immediately thinks, "I needed dough, and if it didn't work out it'd only be Nevin who might look bad for recommending me" (191), and he goes on to quit the job after one day (198). Even seventh-grader Kingsley is a painful character because he looks down on almost everyone around him, an attitude that is at its most palpable when he behaves rudely toward classmate Thomas Hearn because he believes that he possesses superior taste in and understanding of comic books and video games (27-29). I did not feel sympathetic towards or even like these characters - actually, my taste for them was more similar to my taste for sour milk. Like the disgust that remains after smelling or tasting such milk, though, the inconclusive stories caused these nasty characters to linger in my mind. The stories foisted them upon my consciousness, and I therefore could not avoid confronting and reflecting upon these marginalized lives and the more abstract horror of the abject itself.

Although there are a lot of unlikeable characters in Dig, there are a few sympathetic ones, such as the unnamed narrator of "John," and such characters remind us that the abject is undiscriminating, that anyone can become a part of it. Much like the previously discussed Riley (who is also sympathetic), the narrator of "John" suffers from isolation. When they were young teenagers, his best friend Clem Caul taught him vulnerability and intimacy, "how to be a friend" (205), but as an adult, Clem unfortunately seems to have forgotten how to be vulnerable, only wanting a simple good-bye when he is leaving Newfoundland, and thereby preventing the narrator from expressing his feelings. Unable to be emotionally intimate with his friend, the narrator's life has become unlivable, and he says, "on the inside, I felt like I was drowning" (219). These stories show that people can and do throw 
away anything, including positive things like friendship, sometimes for selfish reasons, sometimes unknowingly, and sometimes accidentally, and anyone can get lost in the resulting confusion.

Dig is a well-crafted, thematically timely collection, one that will force readers to think about issues of trash and abjection, both abstractly and in their own lives. The more you think about the stories, the more haunting they become, and the more you realize that the abject is always lurking nearby, encroaching on your space.

\author{
Melanie Hurley \\ Memorial University
}

